\title{
Correction to: Outcomes with sequential FLT3-inhibitor-based therapies in patients with AML
}

\author{
Musa Yilmaz ${ }^{1 \dagger}$, Mansour Alfayez ${ }^{1 \dagger}$, Courtney D. DiNardo ${ }^{1}$, Gautam Borthakur ${ }^{1}$, Tapan M. Kadia ${ }^{1}$, \\ Marina Y. Konopleva', Sanam Loghavi², Rashmi Kanagal-Shamanna², Keyur P. Patel'², Elias J. Jabbour', \\ Guillermo Garcia-Manero', Naveen Pemmaraju', Sherry A. Pierce', Issa Ghayas', Nicholas J. Short', \\ Guillermo Montalban-Bravo ', Koichi Takahashi', Rita Assi', Ahmad S. Alotaibi', Maro Ohanian', \\ Michael Andreeff', Jorge E. Cortes ${ }^{1}$, Hagop M. Kantarjian' ${ }^{1}$, Farhad Ravandi ${ }^{1}$ and Naval G. Daver ${ }^{1 *}$
}

\section{Correction to: J Hematol Oncol (2020) 13:132} https://doi.org/10.1186/s13045-020-00964-5

The original article [18] mistakenly contains duplicate references. The correct reference list can be viewed in this Correction article.

\section{Author details}

${ }^{1}$ Department of Leukemia, The University of Texas MD Anderson Cancer Center, 1515 Holcombe Blvd, Unit FC4.2012, Houston, TX 77030, USA. ${ }^{2}$ Department of Hematopathology, The University of Texas MD Anderson Cancer Center, Houston, TX, USA.

Published online: 23 February 2021

\section{References}

1. Daver N, Schlenk RF, Russell NH, Levis MJ. Targeting FLT3 mutations in AML: review of current knowledge and evidence. Leukemia. 2019:33(2):299-312.

2. Swords R, Freeman C, Giles F. Targeting the FMS-like tyrosine kinase 3 in acute myeloid leukemia. Leukemia. 2012;26(10):2176-85.

\section{The original article can be found online at https://doi.org/10.1186/s1304} 5-020-00964-5.

*Correspondence: NDaver@mdanderson.org

${ }^{+}$Musa Yilmaz and Mansour Alfayez have contributed equally to this work ${ }^{1}$ Department of Leukemia, The University of Texas MD Anderson Cancer Center, 1515 Holcombe Blvd, Unit FC4.2012, Houston, TX 77030, USA

Full list of author information is available at the end of the article
3. Stone RM, Mandrekar SJ, Sanford BL, Laumann K, Geyer S, Bloomfield CD, et al. Midostaurin plus chemotherapy for acute myeloid leukemia with a FLT3 mutation. N Engl J Med. 2017;377(5):454-64.

4. Perl AE, Altman JK, Cortes J, Smith C, Litzow M, Baer MR, et al. Selective inhibition of FLT3 by gilteritinib in relapsed or refractory acute myeloid leukaemia: a multicentre, first-in-human, open-label, phase 1-2 study. Lancet Oncol. 2017;18(8):1061-75.

5. Perl AE, Martinelli G, Cortes JE, Neubauer A, Berman E, Paolini S, et al. Gilteritinib or chemotherapy for relapsed or refractory FLT3-mutated AML. N Engl J Med. 2019:381(18):1728-40.

6. Cortes JE, Khaled S, Martinelli G, Perl AE, Ganguly S, Russell N, et al. Quizartinib versus salvage chemotherapy in relapsed or refractory FLT3ITD acute myeloid leukaemia (QUANTUM-R): a multicentre, randomised, controlled, open-label, phase 3 trial. Lancet Oncol. 2019;20(7):984-97.

7. Cortes JE, Kantarjian H, Foran JM, Ghirdaladze D, Zodelava M, Borthakur $\mathrm{G}$, et al. Phase I study of quizartinib administered daily to patients with relapsed or refractory acute myeloid leukemia irrespective of FMSlike tyrosine kinase 3-internal tandem duplication status. J ClinOncol. 2013;31(29):3681-7.

8. Cortes J, Perl AE, Dohner H, Kantarjian H, Martinelli G, Kovacsovics T, et al. Quizartinib, an FLT3 inhibitor, as monotherapy in patients with relapsed or refractory acute myeloid leukaemia: an open-label, multicentre, singlearm, phase 2 trial. Lancet Oncol. 2018;19(7):889-903.

9. Levis MJ, Smith CC, Ishizuka K, Kobayashi K, Arunachalam M, Wang Y, Lazzaretto D, Cortes JE. Post hoc exploratory analysis of two phase 2 trials of quizartinibmonotherapy in patients (pts) with FLT3-ITD-mutated (mu) relapsed/refractory (R/R) AML with or without prior 1st-generation FLT3 tyrosine kinase inhibitors (TKI) treatment. J ClinOncol. 2018;36:7017.

10. Perl AE. Gilteritinib significantly prolongs overall survival in patients with FLT3-mutated (FLT3mut+) relapsed/refractory (R/R) acute myeloid leukemia (AML): Results from the Phase III ADMIRAL trial. In: Proceedings of the 110th annual meeting of the American Association for Cancer Research; Atlanta, GA.: AACR; 2019.

11. Cortes JE, Tallman MS, Schiller GJ, Trone D, Gammon G, Goldberg SL, et al Phase $2 b$ study of 2 dosing regimens of quizartinibmonotherapy in FLT3ITD-mutated, relapsed or refractory AML. Blood. 2018;132(6):598-607.

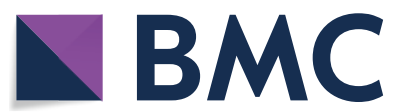

(c) The Author(s) 2021. Open Access This article is licensed under a Creative Commons Attribution 4.0 International License, which permits use, sharing, adaptation, distribution and reproduction in any medium or format, as long as you give appropriate credit to the original author(s) and the source, provide a link to the Creative Commons licence, and indicate if changes were made. The images or other third party material in this article are included in the article's Creative Commons licence, unless indicated otherwise in a credit line to the material. If material is not included in the article's Creative Commons licence and your intended use is not permitted by statutory regulation or exceeds the permitted use, you will need to obtain permission directly from the copyright holder. To view a copy of this licence, visit http://creativecommons.org/licenses/by/4.0/. The Creative Commons Public Domain Dedication waiver (http://creativeco mmons.org/publicdomain/zero/1.0/) applies to the data made available in this article, unless otherwise stated in a credit line to the data. 
12. Cheson BD, Bennett JM, Kopecky KJ, Buchner T, Willman CL, Estey EH, et al. Revised recommendations of the International Working Group for Diagnosis, Standardization of Response Criteria, Treatment Outcomes, and Reporting Standards for Therapeutic Trials in Acute Myeloid Leukemia. J ClinOncol. 2003:21(24):4642-9.

13. Döhner H, Estey E, Grimwade D, Amadori S, Appelbaum FR, Büchner T, et al. Diagnosis and management of AML in adults: 2017 ELN recommendations from an international expert panel. Blood. 2017;129(4):424-47.

14. Ravandi F, Alattar ML, Grunwald MR, Rudek MA, Rajkhowa T, Richie MA, et al. Phase 2 study of azacytidine plus sorafenib in patients with acute myeloid leukemia and FLT-3 internal tandem duplication mutation. Blood. 2013;121(23):4655-62.

15. Rollig C, Serve H, Huttmann A, Noppeney R, Muller-Tidow C, Krug U, et al. Addition of sorafenib versus placebo to standard therapy in patients aged 60 years or younger with newly diagnosed acute myeloid leukaemia (SORAML): a multicentre, phase 2, randomised controlled trial. Lancet Oncol. 2015;16(16):1691-9.
16. NCCN Clinical Practice Guidelines in AML National Comprehensive Cancer Network 2019; Version 3.

17. Swaminathan M, Kantarjian H, Daver N, Borthakur G, Ohanian M, Kadia T, DiNardo C, Jain N, Estrov Z, Ferrajoli A, Garcia-Manero G, Konopleva M, Andreeff M, Pemmaraju N, Jabbour E, Alvarado Y, Wierda W, Pinsoy MR, Ravandi F, Cortes J. The combination of quizartinib with azacitidine or low dose cytarabine is highly active in patients with FLT3-ITD mutated myeloid leukemias: interim report of a phase I/II trial. Blood. 2017;128:1642.

18. Yilmaz M, et al. Outcomes with sequential FLT3-inhibitor-based therapies in patients with AML. J HematolOncol. 2020;13:132. https://doi. org/10.1186/s13045-020-00964-5.

\section{Publisher's Note}

Springer Nature remains neutral with regard to jurisdictional claims in published maps and institutional affiliations.
Ready to submit your research? Choose BMC and benefit from:

- fast, convenient online submission

- thorough peer review by experienced researchers in your field

- rapid publication on acceptance

- support for research data, including large and complex data types

- gold Open Access which fosters wider collaboration and increased citations

- maximum visibility for your research: over $100 \mathrm{M}$ website views per year

At BMC, research is always in progress.

Learn more biomedcentral.com/submissions 